\title{
British are helping to build Amazonian research station
}

Saõ Paulo. In the Caxiuanã forest, 20 hours by boat west of Belém in the Amazonian state of Pará, a 126-year-old dream is becoming reality. With support from Britain's Overseas Development Administration, the Museu Paraense Emílio Goeldi in Belém is

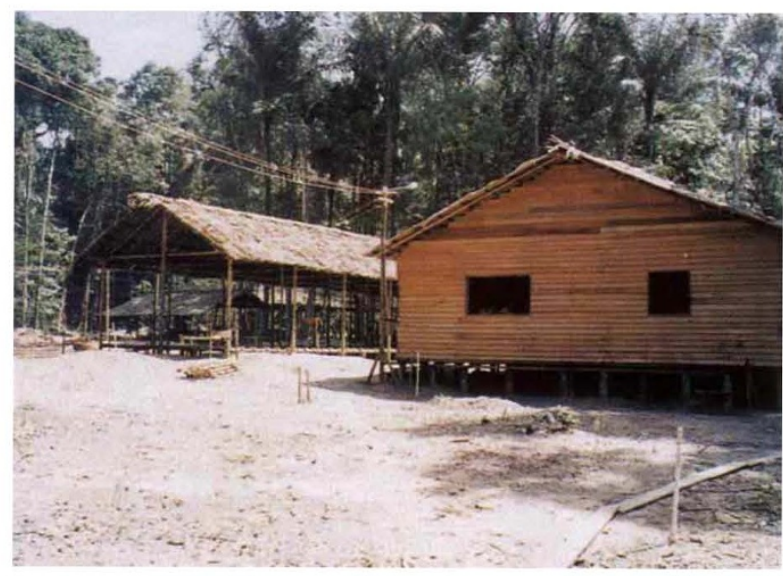

The Goeldi Museum's research station in Amazonia.

building the tropical research station its directors have always wanted.

The Goeldi museum was begun by the nineteenth-century naturalist Domingos Soares Ferreira Penna, but named after Goeldi, a Swiss scientist who came to Brazil in the late 1800s and restored its flagging reputation. By way of historical justice, the forest research station will be named after Ferreira Penna. Seventy per cent of the US $\$ 2.7$ million construction cost comes from the British under the terms of an agreement signed several years ago for cooperative ventures to explore Brazil's rain forests. The station should be finished by May 1993 and will have accommodations and laboratory facilities for 60 scientists and technicians.

The foreign contribution shows that Brazil's research community can attract outside support, but the Goeldi museum is meeting the other 30 per cent of the cost on the promise, says Pedro L.B. Lisboa, the museum's vice-director for research, of important results. "Research programs and projects of high quality have always found a receptive audience among granting agencies both within Brazil and abroad", says Lisboa. But he concedes that "the prospects are greater abroad".

The site in the Caxiuanã National Forest is pristine and sparsely populated, with varied vegetation. About 80 per cent of the 33,000 hectare site is tall, dry-land forest, the rest consisting of patches of floodable vegetation and savannah. The flora is among the richest in eastern Amazonia, according to Lisboa.

Ricardo Bonalume

\section{ESO offers aid to needy astronomers}

Munich. The European Southern Observatory (ESO) is offering practical help to astronomers in eastern and central Europe whose working conditions have deteriorated during recent political upheavals.

ESO has allocated DM 500,000 (US $\$ 310,000$ ) of its DM120 million budget, which provides research facilities for its eight member states in Garching near Munich, for immediate aid to appropriate projects. The programme is primarily intended to help scientists to stay and work in their home institutes. While proposals will be judged on scientific merit, the fundamental needs of the beleaguered community are likely to mean that the grants will be used to ensure basic survival.

Some needs are easier to meet than others. In the last two years, for example, astronomers in Romania's three observatories have organized to assure their mutual survival. But at the Bucharest Observatory 30 scientist must share a single personal computer, leaving some astronomers with only two hours a week of computing time. An ESO grant could remedy this situation by providing additional computers.

Other cases are more challenging. For example, the Byurakan Observatory in Armenia is cut off from access to the outside world and has no fuel and an unreliable supply of electricity. Despite the tremendous hardships, many scientists are trying to keep up some level of activity. However, the observatory is situated atop a mountain $1,500 \mathrm{~m}$ high and must close during the winter.

ESO intends to invite some needy scientists to work for short periods of time at Garching. By acting as a clearing house, ESO also hopes to be able to channel support from other sources such as the European Communities. Alison Abbott
NEWS IN BRIEF

Munich. The heads of Germany's largest scientific research institutes and organizations last week asked their members to take an active stance against hostility towards foreigners.

The alliance, which represents nearly all German scientists, condemned racism and xenophobia and warned that "science, with its many international connections, is especially affected by foreigners' anxiety about Germany". The German research society, the Deutsches Forschung Gemeinschaft (DFG), has already reported that many of its foreign scientists and students now reject living in private accommodation, preferring student halls because of their perceived safety. A group of foreign scholars from the Humboldt Foundation, which promotes international scholastic exchange, were too frightened to leave their bus on a recent trip through cities in eastern Germany, including Rostock.

Institute officials emphasize that very few of their visitors have actually experienced hostility; instead, what they are likely to feel is fear. The statement by the alliance is backed by a national campaign using posters and other forms of advertising.

M.B.

Munich. The European Molecular Biology Conference, the intergovernmental body that finances the Heidelberg-based European Molecular Biology Organization (EMBO), has voted to include three new members: Turkey, Croatia and Portugal. The current membership is limited to 15 Western European countries, plus Israel.

The inclusion of three of Europe's poorest nations demonstrates the commitment of EMBO to the promotion of molecular biology throughout the continent. The political decision has also an element of generosity, as each member country pays as a fixed proportion of its gross national product. As a result, poor countries get out more than they put in.

A.A.

Vienna. Filippo Pandolfi, research minister for the European Communities (EC), last week announced the awarding of nearly 3,000 grants to scientists in Eastern European countries as part of an EC initiative to fund cooperative projects and exchange schemes between the old and the new democracies. Launched earlier this year as the largest programme of research cooperation between East and West, the initiative attracted an unexpectedly high number of applicants $-12,000$. Most of the grants are for short fellowships under the Human Capital and Mobility scheme. Pandolfi said that the research ministry wants to repeat the programme next year but is dependent on a budget request discussed by EC ministers at their meeting last weekend in Edinburgh. This year's awards are worth Ecu55 million (US\$70 million). A.A. 